\title{
SERVANT LEADERSHIP DAN BUDAYA ORGANISASI SEKOLAH TERHADAP KINERJA GURU PADA SEKOLAH MENENGAH ATAS NEGERI DI KOTA PADANG
}

\author{
Fitrah Santosa ${ }^{1}$, Adrianto ${ }^{2}$,Syamsir ${ }^{3}$, Afriva Khaidir ${ }^{4}$ \\ 1 E2STIA BNM Pariaman \\ ${ }_{3} \& 4$ Universitas Negeri Padang \\ Email: fitrahsantosa@gmail.com
}

Article Histori:

Submited: 23/07/2019

Editing: 02/10/2019

Publish: 21/10/2019

\begin{abstract}
The objectives of this study were: 1) to determine the effect of servant leadership on teacher performance in state senior high schools in the city of Padang. 2) to determine the effect of school organizational culture on teacher performance in state senior high schools in the city of Padang. This study used an associative quantitative method, the population of this study were all state senior high school teachers in the city of Padang, with a sample of 292 teachers. Analysis of the data used in this study is a regression analysis technique, in addition, the researchers also used descriptive analysis to obtain a descriptive measurement from each research variables. The results of this study are: 1) servant leadership has a positive and significant effect on teacher performance in State Senior High Schools in the City of Padang. 2) school organizational culture has a positive and significant effect on teacher performance in State Senior High Schools in the city of Padang.
\end{abstract}

Keyword: Servant Leadership, Organizational Culture, and Teacher Performance

\section{PENDAHULUAN}

Pendidikan merupakan salah satu landasan awal bagi tercapainya cita-cita pembangunan ekonomi yang stabil serta terciptanya kesejahteraan masyarakat secara merata. Hal ini dikarenakan sektor pendidikan menjadi salah satu penentu terhadap kualitas sumber daya manusia yang sangat krusial perannya dalam proses pembangunan. Pendidikan dapat meningkatkan kemampuan dan produktivitas seseorang seseorang dalam bekerja sehinga dapat memberikan hasil yang maksimal dan memberikan pengaruh terhadap proses pertumbuhan ekonomi suatu negara (World Bank, 2007).

Penyelenggaraan pendidikan pada hakikatnya harus bisa menciptakan sumber daya manusia yang berkualitas dan berdaya saing tinggi sesuai dengan tujuan pendidikan nasional. Untuk tercapainya tujuan ini, sudah seharusnya pendidikan harus dikelola secara profesional, sehingga hal ini salah satunya sangat ditentukan oleh 
kinerja dari seorang guru, karena guru memiliki peran yang sangat penting dalam proses penyelenggaraan pendidikan nasional tersebut.

Guru dalam hal ini merupakan sumber daya yang semestinya memiliki kemampuan untuk hal itu, oleh karena itu, untuk bisa memiliki kinerja yang profesional perlu dilakukan pembinaan dan pengembangan kemampuan secara terus menerus untuk menghasilkan kinerja yang baik (Susanto, 2016).

Rendahnya kinerja guru dapat menjadi salah satu faktor yang mempengaruhi kualitas pendidikan kita yang rendah dan tidak mampu bersaing dengan masyarakat global secara maksimal. Tidak ada pemakluman terhadap guru yang memiliki kompetensi dibawah standar, karena tinggirendahnya kompetensi seorang guru dinilai dapat mempengaruhi kinerjanya, karena refleksi kompetensi guru itu sendiri adalah kinerja seorang guru tersebut (Susanto, 2016).

Untuk mendapatkan sumber daya manusia yang memiliki kualitas kerja yang optimal, tidak bisa terlepas dari pengaruh berbagai macam faktor yang ada. Keberhasilan kinerja bisa sangat dipengaruhi oleh beberapa faktor seperti kepemimpinan, budaya organisasi, kompensasi, komitmen, kompetensi dan lain-lainnya (Edison Dkk, 2016).

Kepemimpinan dalam suatu organisasi menjadi salah satu faktor yang memiliki pengaruh utama terhadap kinerja individu bawahan serta efektifnya pencapaian kinerja organisasi, demikian juga halnya dengan organisasi pendidikan seperti sekolah. Dalam organisasi pendidikan seperti sekolah formal, faktor yang mempengaruhi terhadap kinerja guru salah satunya bisa berasal dari gaya kepemimpinan yang dimiliki oleh kepala sekolah. Banyak literatur yang menjelaskan bahwa terdapat kaitan antara gaya kepemimpinan kepala sekolah dengan sekolah yang berkualitas, karena gaya kepemimpinan yang tepat akan dapat melahirkan sumber daya manusia yang berkualitas (Hussein Mahmood, 2008).

Kepala sekolah yang baik adalah kepala sekolah yang mampu menggunakan berbagai macam pendekatan kepemimpinan untuk dapat menggerakkan sumberdaya yang ada untuk memperoleh kinerja yang maksimal. Pada saat ini penelitian yang berfokus tentang kepemimpinan kepala sekolah sudah banyak dilakukan dan telah dijadikan sebagai landasan teori untuk melakukan penelitian lanjutan tentang pengaruh gaya kepemimpinan kepala sekolah terhadap kinerja bawahan khususnya kinerja guru.

Salah satu perkembangan dalam penelitian gaya kepemimpinan adalah kepemimpinan yang melayani (servant leadership). Konsep servant leadership ini adalah konsep pemimpin yang berorientasi kepada manusia, yaitu pemimpin yang peduli terhadap pengembangan diri sendiri, orang lain maupun lingkungan disekitarnya. Model kepemimpinan yang melayani (servant leadership) ini memiliki pengaruh terhadap hasil kinerja seseorang (individu) maupun hasil kinerja organisasi (Northouse, 2013).

Kepemimpinan yang melayani (servant leadership) sebagai suatu model kepemimpinan, memiliki prinsip yang mengutamakan peningkatan pertumbuhan pribadi dari para bawahan dengan didasari kepada kriteria-kriteria seperti, kerjasama tim dan pengembangan komunitas, keterlibatan personal dalam proses pembuatan keputusan, serta perilaku yang peduli dan etis terhadap bawahan. Dalam Undang-Undang No. 14 Tahun 2005 tentang Guru dan Dosen pasal 14 terdapat poin yang menyatakan bahwa guru memiliki hak dan kesempatan untuk mengembangkan dan meningkatkan kemampuan dirinya, dan kepala sekolah memiliki peranan penting 
didalam pengembangan tersebut. Peran tersebut dapat terwujud kedalam kegiatan supervisi yang dilakukan oleh kepala sekolah untuk membantu guru yang mengalami kesulitan dalam pengembangan dirinya, sehingga bentuk layanan yang sebaik-baiknya dari kepala sekolah terhadap guru dan tenaga kependidikan yang ada di sekolah dapat mempengaruhi kinerja guru dan tenaga kependidikan tersebut (Asruri, 2016).

Faktor lainnya yang dapat mempengaruhi kinerja seseorang adalah budaya organisasi. Budaya organisasi mengacu kepada suatu sistem pemaknaan bersama yang dianut oleh anggota organisasi dalam bentuk nilai, tradisi, keyakinan (belief), norma, dan cara berfikir unik yang membedakan organisasi itu dari organisasi lainnya (Hasri, 2005). Budaya organisasi dapat juga dilihat sebagai sistem, nilai gabungan, sikap dan kepercayaan yang diterima secara kolektif, dan dijadikan dasar bagi anggota organisasi untuk bertindak sehingga menghasilkan identitas tersendiri yang membedakannya dari organisasi lain (Ibrahim dkk, 2008).

Oleh karena itu, budaya organisasi akan menentukan apa yang boleh dan tidak boleh dilakukan oleh para anggota organisasi, dengan adanya batas-batas normatif yang telah disepakati bersama terhadap perilaku anggota organisasi. Budaya organisasi dapat membentuk cara berperilaku dan berinteraksi anggota organisasi dan mempengaruhi cara kerja mereka (Susanto, 2012).

Tidak jauh berbeda dengan organisasi publik lainnya, sekolah sebagai organisasi pendidikan juga memiliki budaya organisasinya sendiri, yang membedakan dengan organisasi umum lainnya adalah bahwa sekolah memiliki tujuan khusus sebaga penyelenggara layanan bidang pendidikan.
Sehingga, jika seluruh unsur yang ada dalam sekolah dapat membentuk suatu budaya yang kuat dan kondusif berdasarkan karakteristik budaya sekolah tersebut, maka hal tersebut dapat mempengaruhi perilaku orang-orang di dalam sekolah terutama dapat memberikan pengaruh kepada peningkatan kinerja guru.

Kondisi dari lingkungan internal, lingkungan eksternal dan budaya organisasi akan sangat menentukan kepada kinerja sumber daya manusia yang ada didalam organisasi tersebut (Wibowo, 2013). Hal ini juga berlaku pada organisasi pendidikan seperti sekolah, dimana budaya sekolah yang dianut dan diterapkan oleh suatu sekolah akan mampu mempengaruhi kinerja guru dan pegawai di sekolah yang bersangkutan (Susanto, 2016).

Pentingnya pendidikan terhadap peningkatan kualitas hidup manusia tidak lepas dari peran guru serta kinerjanya, dari hasil observasi yang dilakukan oleh peneliti terhadap beberapa sekolah menengah atas di kota Padang, terlihat bahwa masih ada oknumoknum guru yang memiliki komitmen kerja yang tidak memuaskan. Masih ditemukannya tindakan-tindakan tidak profesional yang dilakukan oleh beberapa oknum guru seperti datang terlambat dan pulang ketika kepala sekolah tidak berada di tempat. Sehingga, hal ini tentu saja berpengaruh terhadap penyelenggaraan pendidikan nasional yang nantinya akan berdampak kepada rendahnya kualitas sumber daya manusia yang dimiliki oleh bangsa ini. Oleh karena itu untuk mendalami serta pengembangan lebih lanjut terhadap kajian kepemimpinan khususnya gaya kepemimpinan yang melayani (servant leadership), budaya organisasi sekolah, dan kinerja guru, peneliti tertarik untuk melakukan penelitian tentang pengaruh kepemimpinan yang melayani (servant leadership) dan budaya 
organisasi sekolah terhadap kinerja guru pada sekolah menengah atas negeri di kota padang.

\section{METODE PENELITIAN}

Penelitian ini menggunakan metode kuantitatif asosiatif. Penelitian asosiatif merupakan penelitian yang bertujuan untuk mengetahui pengaruh ataupun hubungan antara dua variabel atau lebih (Sugiyono, 2016). Metode ini dipilih karena penelitian ini bertujuan untuk mengungkap seberapa besar pengaruh kedua variable bebas yaitu, gaya kepemimpinan yang melayani (servant leadership), dan budaya organisasi sekolah terhadap variabel terikat yaitu kinerja guru.

Penelitian dilakukan di Kota Padang, pada sekolah menengah atas negeri dengan jumlah 16 sekolah negeri. Adapun populasi dalam penelitian ini adalah seluruh guru di sekolah menengah atas negeri di Kota Padang dengan jumlah populasi sebanyak 1071 orang guru. Untuk mendapatkan jumlah sampel yang representatif, maka peneliti menggunakan rumus Slovin dalam penentuan jumlah sampel yang akan mewakili total keseluruhan populasi guru sekolah menengah atas negeri di Kota Padang, yaitu sebagai berikut

$$
\mathrm{n}=\frac{N}{1+N\left(e^{2}\right)}
$$

Dalam penelitian ini dengan jumlah $\mathrm{N}=$ 1071 dengan tingkat kesalahan $\left(\mathrm{e}^{2}\right)$ sebesar $5 \%$, sehingga sampel yang ditemukan adalah sebagai berikut:

$$
\begin{aligned}
& \mathrm{n}=\frac{1071}{1+1071(5 \%)^{2}} \\
& \mathrm{n}=\frac{1071}{1+1071(0.05)^{2}} \\
& \mathrm{n}=\frac{1071}{1+2,67} \\
& \mathrm{n}=\frac{1071}{3,67} \\
& \mathrm{n}=291,82 \rightarrow 292
\end{aligned}
$$

Dari hasil perhitungan berdasarkan rumus slovin diatas, ditemukan jumlah sampel dari keseluruhan jumlah populasi guru sekolah menengah atas negeri di Kota Padang adalah sebanyak 292 orang.

Kemudian untuk penetapan guru pada tiap-tiap sekolah yang akan dijadikan sampel, peneliti menggunakan teknik proporsional random sampling. Penarikan sampel dilakukan tanpa memperhatikan srata yang ada dalam populasi, hal ini dilakukan karena anggota populasi dianggap homogen (Sugiyono, 2016).

Penelitian ini adalah penelitian survey sehingga untuk pengumpulan data dalam penelitian ini akan menggunakan angket sebagai intrumen penelitian. Dimana angket tersebut terdiri dari beberapa pertanyaan/pernyataan yang bersifat tertutup dan untuk mengetahui/mengukur bagaimana jawaban responden terhadap pertanyaan/pernyataan yang diajukan dalam angket, maka akan digunakan likert summated ratings.

Dalam penelitian ini, teknik analisis yang digunakan adalah teknik analisis statistik deskriptif yang digunakan untuk untuk mendapatkan gambaran tentang pengukuran setiap variabel dalam penelitian, serta teknik teknik analisis regresi yang digunakan untuk pengujian terhadap hipotesis penelitian ini. adapun teknik analisis persamaan regresi dalam penelitian ini terdiri dari:

a. Uji T (Parsial)

Uji T (parsial) dilakukan untuk mengetahui sejauh mana besaran pengaruh variabel independen $(X)$ terhadap variabel dependen (Y) secara parsial. Pengujian hipotesis akan dilakukan berdasarkan tingkat signifikansi sebesar 0,05 $(\alpha=5 \%)$ atau tingkat keyakinan sebesar 0,95 (95\%). Teknik yang akan digunakan untuk menguji hipotesis penelitian ini secara parsial dirumuskan sebagai berikut:

1. Untuk menguji pengaruh gaya kepemimpinan yang melayani (servant leadership) terhadap kinerja guru, peneliti 
menggunakan teknik analisis regresi sederhana.

2. Untuk menguji pengaruh budaya organisasi sekolah terhadap kinerja guru, peneliti menggunakan teknik analisis regresi sederhana.

\section{HASIL DAN PEMBAHASAN}

\section{Uji T}

\section{a. Pengaruh Servant Leadership Terhadap Kinerja Guru}

Uji $\mathrm{T}$ dilakukan untuk mengetahui tingkat signifikansi dari servant leadership (kepemimpinan yang melayani) terhadap kinerja guru pada sekolah menengah atas negeri di Kota Padang, adapun hasil uji T dari pengaruh servant leadership terhadap kinerja guru dapat terlihat pada tabel 1 di bawah ini.

\section{Tabel 1. Hasil regresi linear servant leadership (X1) terhadap kinerja guru $(\mathrm{Y})$}

\begin{tabular}{cccc}
\hline Variabel X1 & $\begin{array}{c}\text { Adjusted } \\
\text { R Square }\end{array}$ & $\begin{array}{c}\mathbf{t} \\
\text { Hitung }\end{array}$ & $\begin{array}{c}\text { Coefficients } \\
\text { Sig }\end{array}$ \\
\hline $\begin{array}{c}\text { Servant } \\
\text { Leadership }\end{array}$ & 0,149 & 7,204 & 0,000 \\
\hline
\end{tabular}

Dependent variable: Kinerja Guru

Dari tabel 1, ditemukan nilai signifikansi servant leadership sebesar 0,00 < 0,05 . Sehingga dapat disimpulkan bahwa variabel servant leadership memiliki pengaruh positif yang signifikan terhadap kinerja guru. Adapun besaran pengaruh dari variabel servant leadership terhadap variabel kinerja guru dapat terlihat pada nilai Adjusted R Square tabel 1 yaitu sebesar 0,149 , yang artinya variabel servant leadership memiliki pengaruh sebesar $14,9 \%$ terhadap kinerja guru pada sekolah menengah atas negeri di Kota Padang.

Hasil penelitian ini sejalan dengan apa yang diungkapkan oleh Srimulyani dan Hutajulu (2013) yang melakukan penelitian tentang dampak servant leadership terhadap kinerja guru pada guru-guru SMA dan SMK di Kota Madiun, bahwa gaya kepemimpinan servant leadership seorang kepala sekolah memiliki pengaruh positif dan signifikan terhadap kinerja guru tersebut. Hal serupa juga diungkapkan oleh Asruri (2016) yang juga melakukan penelitian tentang servant leadership dan pengaruhnya terhadap kinerja guru, yang mengungkapkan bahwa bentuk layanan yang diberikan kepala sekolah terhadap guru-gurunya dapat mempengaruhi kinerja guru tersebut.

Northouse

turut mengemukakan bahwa salah satu tujuan akhir dari model servant leadership ini adalah kinerja pengikut. Menurut Northouse sendiri, ketika prinsip-prinsip servant leadership tersebut berjalan dengan baik hal ini akan memberikan hasil positif terhadap kinerja pengikut, dimana pengikut/bawahan akan menjadi lebih efektif dalam menyelesaikan dan melakukan pekerjaan mereka. Pendapat yang dikemukakan oleh Northouse tersebut sesuai dengan temuan penelitian ini yang menemukan bahwa konsep/karakter servant leadership yang diterapkan oleh seorang kepala sekolah akan memiliki pengaruh positif terhadap kinerja guru sebagai pengikut/bawahan dari kepala sekolah tersebut.

Adapun tingkat capaian responden untuk variabel kepemimpinan yang melayani (servant leadership) ini sendiri berada pada tahap baik dengan skor TCR sebesar $83,50 \%$, sehingga dapat disimpulkan bahwa dengan menerapkan konsep-konsep servant leadership sebaik-baiknya maka secara langsung dapat meningkatkan kinerja guru kearah yang lebih baik lagi.

\section{b. Pengaruh Budaya Organisasi Sekolah Terhadap Kinerja Guru}


Sedangkan hasil uji $\mathrm{T}$ untuk pengaruh budaya organisasi sekolah terhadap kinerja guru pada sekolah menengah atas negeri di Kota Padang ditemukan hasil sebagai berikut:

Tabel 2. Hasil regresi linear budaya organisasi sekolah (X2) terhadap kinerja guru

\begin{tabular}{crcc}
\hline Variabel & $\begin{array}{c}\text { Adjusted } \\
\text { R Square }\end{array}$ & $\begin{array}{c}\mathbf{t} \\
\text { Hitung }\end{array}$ & $\begin{array}{c}\text { Coefficients } \\
\text { Sig }\end{array}$ \\
\hline $\begin{array}{c}\text { Budaya } \\
\text { Organis } \\
\text { asi }\end{array}$ & 0,179 & $\begin{array}{c}8,02 \\
6\end{array}$ & 0,000 \\
Sen & & 6 &
\end{tabular}

Sekolah

Dependent variable: Kinerja Guru

Dari tabel 2 ditemukan nilai signifikansi variabel budaya organisasi sekolah sebesar $0,00<0,05$ sehingga dapat diartikan bahwa variabel budaya organisasi sekolah memiliki pengaruh positif yang signifikan terhadap kinerja guru. Dari tabel 2 juga ditemukan nilai Adjusted R Square sebesar 0,179 atau dapat diartikan juga bahwa variabel budaya organisasi sekolah memiliki besaran pengaruh sebesar 17,9\% terhadap variabel kinerja guru pada sekolah menengah atas negeri di Kota Padang.

Temuan penelitian ini sejalan dengan hasil temuan penelitian relevan sebelumnya yang dilakukan oleh Manik dan Bustomi (2011), dimana berdasarkan dari hasil penelitian mereka ditemukan hasil bahwa budaya organisasi berpengaruh secara signifikan terhadap kinerja guru. Penelitian lainnya yang sejalan dengan temuan penelitian ini adalah penelitian yang dilakukan oleh Handayani dan Rasyid (2015), dimana dalam hasil penelitian yang mereka lakukan juga ditemukan hasil bahwa budaya organisasi memiliki pengaruh yang signifikan terhadap kinerja guru.

Hasil penelitian ini juga sesuai dengan pendapat yang dikemukakan oleh Susanto (2016) yang menyatakan bahwa budaya organisasi sekolah dapat memberikan pengaruh terhadap kinerja guru. Kinerja guru akan lebih efektif jika guru tersebut memiliki komitmen dan loyalitas terhadap budaya organisasi sekolah yang merupakan suatu ciri atau identitas yang dimiliki sebuah sekolah tersebut. Kinerja yang efektif dapat tercapai apabila sekolah memiliki budaya organisasi yang kuat. Dalam penelitian ini, kategori capaian budaya organisasi sekolah sendiri berada pada tahap baik dengan skor TCR mencapai $85,99 \%$. Sehingga dapat diartikan bahwa penerapan nilai-nilai budaya organisasi sekolah yang baik dalam suatu sekolah terutama Sekolah Menengah Atas Negeri di Kota Padang secara langsung dapat meningkatkan kinerja guru kearah yang lebih baik lagi.

\section{PENUTUP}

Tujuan awal dari penelitian ini dilakukan adalah untuk mengetahui apakah terdapat pengaruh dari variabel kepemimpinan yang melayani (servant leadership) dan budaya organisasi sekolah terhadap kinerja guru pada sekolah-sekolah menengah atas negeri di Kota Padang. Setelah dilakukan penelitian dan dilakukan uji hipotesis penelitian, maka didapatkan kesimpulan penelitian sebagai berikut:

1. Terdapat pengaruh yang signifikan dari servant leadership terhadap kinerja guru pada sekolah menengah atas negeri di Kota Padang.

2. Terdapat pengaruh yang signifikan dari budaya organisasi sekolah terhadap kinerja guru pada sekolah menengah atas negeri di Kota Padang.

\section{DAFTAR PUSTAKA}

Asruri, Ali. (2016). Servant Leadership Kepala Sekolah Di Sd Negeri 1 Grobogan Kabupaten Grobogan. Tesis Program Studi Magister Administrasi Pendidikan Sekolah Pascasarjana Universitas Muhammadiyah Surakarta 
E. Edison, Y. Anwar, I. Komariyah. (2016). Manajemen Sumber Daya Manusia. Bandung. Alfabeta.

Ester Manik, Kamal Bustomi. (2011). Pengaruh Kepemimpinan Kepala Sekolah, Budaya Organisasi dan Motivasi Kerja Terhadap Kinerja Guru Pada SMP Negeri 3 Rancaekek. Jurnal Ekonomi, Bisnis \& Entrepreneurship, Vol 5, No 2. Sekolah Tinggi Ilmu Ekonomi Pasundan.

Hasri, Salfen. (2005). Manajemen Pendidikan: Pendekatan Nilai dan Budaya Organisasi. Makassar. Yapma

Hussein Mahmood. (2008). Kepimpinan dan Keberkesanan Sekolah. Edisi Kedua, Dewan Bahasa dan Pustaka Kuala Lumpur.

Mohammed Sani Ibrahim, Mohd Izham Mohd Hamzah, Jainabee MD L.S. Kassim, (2008). Sekolah Berkesan, Konsep dan Ciri Utama. Bangi . Universiti Kebangsaan Malaysia.

Northouse,Peter G. (2013). Kepemimpinan. Teori dan Praktik, edisi keenam. Jakarta. Indeks.

Susanto, Ahmad. (2016). Manajemen Peningkatan Kinerja Guru. Jakarta. Prenada Media Grup.

Susanto, Hary. (2012). Faktor-Faktor Yang Mempengaruhi Kinerja Guru Sekolah Menengah Kejuruan. Jurnal Pendidikan Vokasi, Vol 2, No 2,. Universitas Negeri Yogyakarta.

Sugiyono. (2016). Metode Penelitian Kuantitatif, Kualitatif dan RED. Bandung. Alfabeta.

Titik Handayani, Aliyah A. Rasyid. (2015). Pengaruh Kepemimpinan Kepala Sekolah, Motivasi Guru, dan Budaya Organisasi Terhadap Kinerja Guru SMA Negeri Wonosobo. Jurnal Akuntabilitas Manajemen Pendidikan, e ISSN 24610550. Vol. 3 No. 2.
Undang-Undang No. 14 Tahun 2005 Tentang Guru dan Dosen

Wibowo. (2013). Budaya Organisasi: Sebuah Kebutuhan untuk Meningkatkan Kinerja. Jakarta. Rajawali Pers.

World Bank. (2007). Education Quality and Economic Growth. 